\title{
THE INFLUENCES OF LACTOBACILLUS CELL-FREE SUPERNATANTS ON GROWTH AND VIRULENCE PROPERTIES OF CAMPYLOBACTER JEJUNI IN HUMAN ADENOCARCINOMA (HT-29) CELL CULTURE
}

\author{
LAKTOBASILLERDEN ELDE EDILEN HÜCRESIZ SÜZÜNTÜLERIN INSAN \\ ADENOKARSINOM (HT-29) HÜCRE KÜLTÜRÜNDE CAMPYLOBACTER JEJUNI'NIN \\ ÜREME VE VIRÜLANS ÖZELLIKLERI ÜZERINE ETKILERI
}

\author{
Fatma KALAYCI YÜKSEK ${ }^{1}$, Defne GÜMÜŞ ${ }^{1}$ D, Varol GÜLER² (D), Aysun UYANIK ÖCAL ${ }^{1}$ (D), Mine ANĞ KÜÇÜKER \\ ${ }^{1}$ Istanbul Yeni Yüzyıl University, Faculty of Medicine, Department of Medical Microbiology, Istanbul, Turkey \\ ${ }^{2}$ Istanbul Yeni Yüzyıl University, Faculty of Medicine, Department of Medical Biology and Genetic, Istanbul, Turkey
}

ORCID IDs of the authors: F.K.Y. 0000-0002-0028-5646; D.G. 0000-0003-4070-6924; V.G. 0000-0002-8726-330X;

A.U.Ö. 0000-0001-5255-0133; M.A.K. 0000-0001-8978-219X

Cite this article as: Kalayci Yuksek F, Gumus D, Guler V, Uyanik Ocal A, Ang Kucuker M. The influences of Lactobacillus cell-free supernatants on growth and virulence properties of Campylobacter jejuni in human adenocarcinoma (HT-29) cell culture. J Ist Faculty Med. Published online February 7, 2022. doi: 10.26650/IUITFD.984009

\begin{abstract}
Objective: Lactobacilli are the most commonly used probiotics. We examined the influence of cell-free supernatants (CFSs) of Lactobacillus acidophilus (La), L. fermentum (Lf), L. plantarum $(L p)$ and $L$. rhamnosus ( $L r)$ on growth, adhesion and invasion of C. jejuni 81116 and RM1221 in human adenocarcinoma colon cells (HT-29). We also analyzed the influences of CFSs, C. jejuni and their combinations on HT-29 cell viability.
\end{abstract}

Materials and Methods: Growth and adhesive-invasive bacteria counts were determined using the spectrophotometric method and colony counting method, respectively. We used methyl thiazolyl diphenyl-tetrazolium bromide (MTT) assay for detection of HT-29 cell viability.

Results: During two and four hours of incubation, the growth of RM1221 was significantly decreased $(p<0.0001)$ with the effects of the tested CFSs, while the decrease in growth of the 81116 strain was only significant $(p<0.05)$ in the presence of $L a$ and $L p$. All CFSs except La reduced the growth of both $C$. jejuni isolates at 24 hours of incubation. The adhesion of C. jejuni 81116 was significantly $(p<0.0001)$ reduced in the presence of all CFSs. La and Lr statistically significantly $(p<0.05$ and $p<0.005$, respectively) reduced the adhesion of $C$. jejuni RM1221. Invasion of $C$. jejuni strains was shown not to be affected in presence of all CFSs. C. jejuni and each CFSs were found to influence the HT-29 viability differently.

\section{ÖZET}

Amaç: Laktobasiller en yaygın kullanılan probiyotiklerdendir. ÇaIışmamızda, Lactobacillus acidophilus (La), L. fermentum (Lf), L. plantarum (Lp) ve L. rhamnosus (Lr)'nin hücresiz süzüntülerinin (CFS) C. jejuni suşlarının (81116 ve RM1221) üremesi, adezyonu ve invazyonu üzerine etkilerini inceledik. Aynı zamanda, CFS'lerin, C. jejuni suşlarının ve CFS+C. jejuni kombinasyonlarının HT29 hücre canlılığındaki etkilerini araştırdık.

Gereç ve Yöntem: Üreme ile adezif ve invazif bakterilerin sayıları, sırasıyla, spektrofotometrik ve koloni sayma yöntemleri ile belirlenmiştir. Çalışmamızda, Metil tiazolil difeni-tetrazolium bromid (MTT) deneyini, hücrelerin (HT-29) canlılığını belirlemede kullandık.

Bulgular: İki ve dört saatlik inkübasyonlarda, tüm CFS'ler RM1221 suşunun, La ve Lp CFS'leri ise, 81116 suşunun üremesini anlamlı düzeyde azaltmıştır (sırasıyla, $p<0,0001, p<0,05$ ). Tüm CFS'ler (La hariç) 24 saatlik inkübasyonda her iki suşun da üremesini baskılamıştır. C. jejuni 81116'nin adezyonu tüm CFS'lerin varlığında istatistiksel olarak anlamlı düzeyde baskılanmıştır $(p<0,0001)$. C. jejuni RM1221'nin adezyonu La ve Lr süzüntüleri varlığında istatistiksel olarak anlamlı düzeyde baskılanmıştır (sırasıyla, $p<0,05$ ve $p<0,005)$. Suşların invazyon özellikleri süzüntülerin varlığında etkilenmemiştir. HT-29 hücrelerinin canlılığı hem C. jejuni'nin ve hem de her bir CFS'nin varlığında farklı yönlerde etkilenmiş̧tir.

Corresponding author/iletişim kurulacak yazar: fatma.kalayci@yeniyuzyil.edu.tr

Submitted/Başvuru: 17.08.2021 • Revision Requested/Revizyon Talebi: 11.10.2021 •

Last Revision Received/Son Revizyon: 27.11.2021 • Accepted/Kabul: 20.12.2021 • Published Online/Online Yayın: 07.02.2022 
Conclusion: Our results suggest that CFSs have suppressive effects on the growth and adhesive properties of $C$. jejuni in a time-dependent manner. The viability of HT-29 depends on incubation time and which strain is tested.

Keywords: C. jejuni, lactobacilli, growth, adhesion, invasion, cell viability
Sonuç: Sonuçlarımız CFS'lerin C. jejuni'nin üreme ve adezyonunu temas süresine bağlı olarak baskıladıklarını göstermektedir. HT-29 hücrelerinin canlılığı inkübasyon süresi ve incelenen suşa bağlı olarak etkilenmiştir.

Anahtar Kelimeler: C. jejuni, laktobasiller, üreme, adezyon, invazyon, hücre canlılığı

\section{INTRODUCTION}

Probiotics are known as living microorganisms that provide advantages for the host's health by stimulating the immune system, competing with pathogens for receptor binding and production of acids, bacteriocins, bio-surfactants and hydrogen peroxide to inhibit pathogens (1-4). In recent years, many studies have reported the roles of probiotics not only as supportive therapeutics but also as an alternative treatment method for infectious diseases, gastrointestinal tract diseases and control of oral health. Lactobacilli are known as the most commonly used probiotic microorganisms (5-7). Although they are known to have inhibitory effects on pathogens, the effects of their products have not been investigated extensively on Campylobacter jejuni.

C. jejuni, a foodborne pathogen, causes gastroenteritis and can be responsible for post-infectious complications in humans $(8,9)$. Adhesion-invasion mechanisms of the bacterium are very important during infectious processes and are related to cell death and the distribution of mucosal barriers in the host $(10,11)$. The increase of antibiotic-resistant strains is an important problem that leads to public health concerns and an economic burden (8, 9). Therefore, alternative and supportive options need to be considered. There are studies that present promising results to cope with stages of infection using the antagonist relationship between probiotic microorganisms and pathogens (12-20).

This study aimed to investigate the influence of lactobacilli cell-free supernatants (CFSs) on the growth and virulence properties (adhesion and invasion abilities) of two C. jejuni strains (81116 and RM1221) in the human adenocarcinoma cells (HT-29), mimicking host conditions. The study also examined the effects of $C$. jejuni strains and CFSs of lactobacilli, together or separately, on the viability of HT-29 cells.

\section{MATERIALS AND METHODS}

\section{Bacteria and preparing of cell-free supernatants}

Two Campylobacter strains (C. jejuni 81116 and RM1221) were kindly provided by Dr. György Schneider, (University of Pécs, Hungary). C. jejuni strains were grown in Brucella broth (BB) (Besimik, Turkey) under microaerophilic conditions at $37^{\circ} \mathrm{C}$ for 48 hours.
Lactobacilli (Lactobacillus acidophilus ATCC 314-La, L. fermentum ATCC 9338-Lf, L. plantarum ATCC 14917-Lp and L. rhamnosus ATCC 53103-Lr), which are commonly sold in pharmacies and markets, were examined (21, 22).

De-Man Rogosa-Sharpe (MRS) broth (Conda, Spain) was used on growth of Lactobacilli under anaerobic conditions at $37^{\circ} \mathrm{C}$ for 24 hours. Following overnight cultivation of Lactobacillus strains, supernatants were collected via centrifugation at $4000 \mathrm{rpm}$ for 30 minutes at $4^{\circ} \mathrm{C}$, then filtered with $0.2 \mu \mathrm{m}$ pore size filters $(12,23)$.

\section{Cell culture}

Human colon adenocarcinoma cells (HT-29) were used in our experiments and specific cell culture conditions as previously defined $(13,15)$.

HT-29 cells were seeded in 96-well microplates for bacterial growth and cell viability assay, seeded in 24-well plates for invasion and adhesion experiments. To provide a confluent monolayer cell culture, density was adjusted as approximately $5 \times 10^{4}$ cells for 24 -well and $1 \times 10^{4}$ cells for 96 -well plates. Plates were incubated at $37^{\circ} \mathrm{C}$, under $5 \% \mathrm{CO}_{2}$ conditions for 24 hours.

\section{Infection of HT-29 cells with $C$. jejuni}

The overnight cultures of Campylobacter isolates were prepared in Brucella broth at $37^{\circ} \mathrm{C}$. For infection of HT-29 cells, a suspension of approximately $10^{9} \mathrm{CFU} / \mathrm{mL}$ of each strain was used.

Before inoculation of C. jejuni, Dulbecco's Modified Eagle Medium (DMEM) containing antibiotics was replaced with antimicrobial solution-free DMEM and CFSs were added into each well $(20 \mu \mathrm{L}$ in each 96 -well plates and 50 $\mu \mathrm{L}$ in each 24-well plates). The plates were incubated for one hour at $37^{\circ} \mathrm{C}$.

HT-29 cells were inoculated with C. jejuni and microaerophilic conditions were provided for incubation (as seen below). All assays were performed three times.

\section{Bacterial growth}

Bacteria were incubated for two, four and 24 hours to investigate the alterations of growth in the presence/absence of CFSs. The influence of each CFSs was detected by measuring the changes in absorbance at $600 \mathrm{~nm}$. Bac- 
terial growth in cell culture with CFSs was compared to cell culture without CFSs (as negative control).

\section{Bacterial adhesion and invasion}

HT-29 cells were incubated with $C$. jejuni for three hours at $37^{\circ} \mathrm{C}$ under microaerophilic conditions. The effect of each CFS on bacterial adhesion and invasion was determined by comparing colony counts (as $\mathrm{CFU} / \mathrm{mL}$ ) from cell lysates of HT-29 grown in the presence/absence of CFSs. We determined colony counts of adhesive and invasive bacteria as described previously $(24,25)$.

\section{Bacterial adhesion}

Phosphate buffer saline (PBS) was used to wash the wells three times to remove unbound bacteria after incubation for three hours. Then, the cells were lysed using $500 \mu \mathrm{l} 1 \%$ Triton X-100 for 10 minutes at $37^{\circ} \mathrm{C}$ under $5 \% \mathrm{CO}_{2}$ conditions. Following the homogenization and inoculation of cell lysates on Mueller-Hinton agar (MHA) (Spesera, Turkey) supplemented with sheep blood (5\% defibrinated), media was incubated at $37^{\circ} \mathrm{C}$ for 48 hours under microaerophilic conditions.

\section{Bacterial invasion}

After bacterial inoculation and three hours incubation, the wells were washed with PBS three times. Then, a medium supplemented with $300 \mathrm{ng} / \mathrm{ml}$ gentamicin was added to each well for killing non-invasive (extracellular) bacteria. Microaerophilic conditions were provided for incubation of the plates and they were incubated for two hours at $37^{\circ} \mathrm{C}$. The lyses of HT-29 cells were provided using Triton $\mathrm{X}-100$ as mentioned above. For detection of invasive bacteria, the homogenized cell lysates were inoculated on MHA (Spesera, Turkey) supplemented with sheep blood and incubated for 48 hours under microaerophilic conditions at $37^{\circ} \mathrm{C}$.

\section{Viability of Human adenocarcinoma colon cells (HT-29)} A methyl thiazolyl diphenyl-tetrazolium bromide (MTT) assay was used for detecting cell viability. The effects of CFSs and C. jejuni, together and separately, on the viability of HT-29 were investigated. Experimental conditions were prepared as mentioned above and HT-29 cells were incubated for 24 and 48 hours under microaerophilic conditions.

Following incubation, the wells were washed with PBS three times to remove residue. Then, a fresh culture medium was added. According to Mosmann, MTT was prepared (12 mM, Neofrox 3580 MTT) and added into each well. The HT-29 cells were incubated at $37^{\circ} \mathrm{C}$ for four hours under microaerophilic conditions (26).

After incubation, the media were aspirated to remove the content from the wells. Then, Dimethyl sulfoxide (DMSO) was added into each well. The plates were incubated at room temperature for 10 minutes to dissolve the for- mazan crystals into a colored solution. Lastly, absorbance values were measured at $540 \mathrm{~nm}$ via the spectrophotometric method.

The cell viability of HT-29 was investigated by comparing the absorbance values of dissolved formazan crystals produced by HT-29 cells in the presence/absence of CFSs or C. jejuni, separately and together.

\section{Statistical analysis}

The significant differences between experimental conditions and control conditions were calculated. Results were analyzed with two-way ANOVA followed by Dunnett's multiple comparisons test for growth alterations. One-way ANOVA followed by Dunnett's multiple comparisons test was performed for adhesion and invasion results. Alterations of cell viability were detected by two-way ANOVA followed by Dunnett's and Sidak's multiple comparisons test. The significant differences between experimental conditions and control conditions were evaluated. All results were presented as mean \pm SD. Differences with $p$ values less than 0.05 were accepted as indicative of statistically significant differences.

\section{RESULTS}

\section{Bacterial growth}

After incubation for two and four hours, CFSs of La and L $p$ significantly reduced $(p=0.046$ and $p=0.039$, respectively for two hours and $p=0.043$ and $p=0.029$, respective$l y$, for four hours) the growth of $C$. jejuni 81116 strain; all CFSs decreased significantly $(p<0.0001)$ the growth of $C$. jejuni RM1221 (Figure 1a, Figure 1b).

According to the 24 hour incubation results, the growth C. jejuni 81116 strain was statistically significantly decreased ( $p=0.0034$ for $L f, p<0.0001$ for $L p$ and $p=0.0025$ for $L r)$ in the presence of all CFSs except for La. It was found that all CFSs were shown to decrease $(p<0.0001)$ the growth of $C$. jejuni RM1221 statistically significantly. Furthermore, the most effective inhibition was seen for C. jejuni RM1221 in the presence of each CFSs at 24 hours incubation (Figure 1b).

\section{Bacterial adhesion}

The adhesion of $C$. jejuni 81116 was found to be significantly reduced $(p<0.0001)$ in the presence of all CFSs. $\mathrm{La}$ and $\mathrm{Lr}$ CFSs' were found to significantly reduce ( $p=0.0068$, and $p=0.026$, respectively) the adhesion of $C$. jejuni RM1221 (Figure 2).

\section{Bacterial invasion}

The effects of all CFSs on bacterial invasion were found statistically insignificant $(p>0.05)$ for both $C$. jejuni strains (Figure 3). 


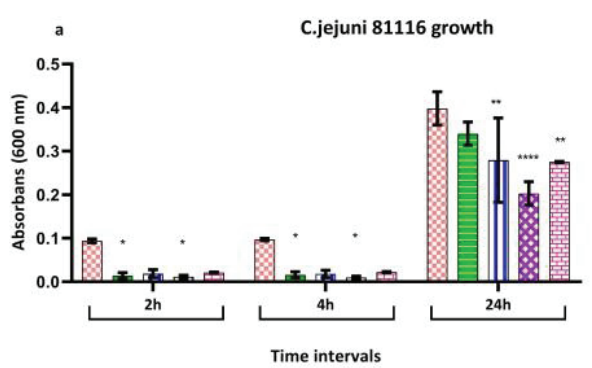

国 HT-29+C.jejuni 81116 (control)

HT-29+C.jejuni $81116+$ La CFS III HT-29+C.jejuni 81116+LfCFS
WT-29+C.jejuni 81116+Lp CFS HT-29+C.jejuni $81116+$ Lr CFS

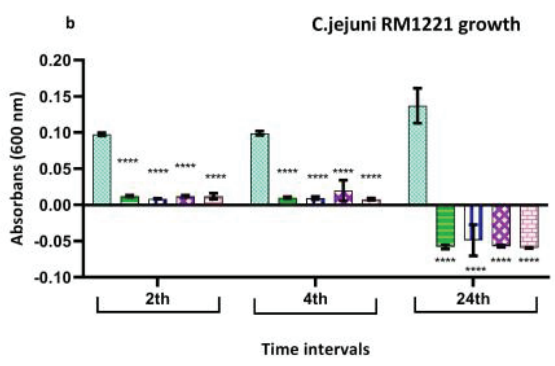

$\square$ HT-29+C.jejuni RM1221 (control)

HT-29+C.jejuni RM1221+La CFS III HT-29+C.jejuni RM1221+Lf CFS
HT-29+C.jejuni RM1221+Lp CFS

WT-29+C.jejuni RM1221+Lr CFS

Figure 1: The influences of CFSs on the growth of C. jejuni

The growth of $\mathrm{C}$. jejuni grown in HT-29 with and without CFSs were examined using two way ANOVA followed by Dunnett's multiple comparisons test.

$*^{*} * * * \star *$ : Significance levels were as $p<0.05, p<0.005$ and $p<0.0001$, respectively.

a

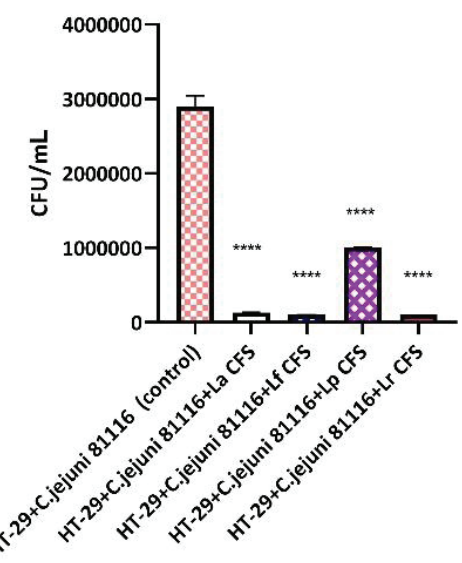

b

C.jejuni RM1221 adhesion
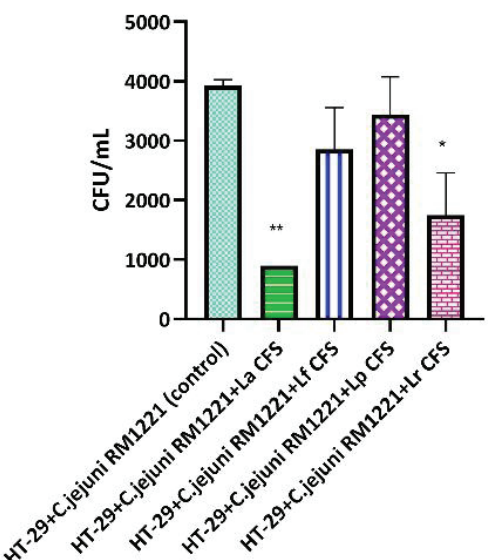

Figure 2: The influences of CFSs on adhesion of C. jejuni

The adhesion of $C$. jejuni in HT-29 with/without CFSs was analyzed using one-way ANOVA followed by Dunnett's multiple comparisons test. $*, * *, * \star \star *$ : Significance levels were as $p<0.05, p=0.0068$ and $p<0.0001$, respectively.
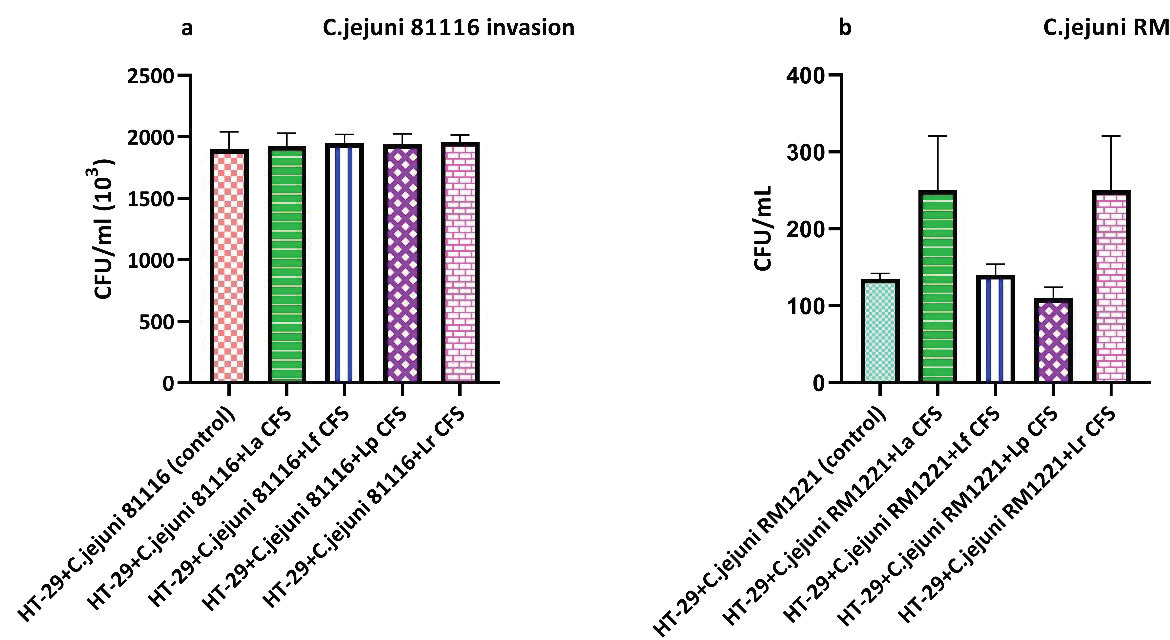

Figure 3: The influences of CFSs on the invasion of C. jejuni

The invasion of C. jejuni in HT-29 with/without CFSs was analyzed using one-way ANOVA followed by Dunnett's multiple comparisons test. 


\section{Viability of HT-29 cells}

According to the 24 hour incubation results, the viability of HT-29 cells infected with C. jejuni RM1221 increased $(p<0.0001)$. The HT-29 cell viability was shown to be decreased significantly $(p<0.0001)$ by each CFSs (Figure 4).

After 48 hours, the HT-29 cell viability was significantly reduced in the presence of CFSs (Lf- $p=0.001, L p-p<0.0001$ and Lr- $p=0.0005)$ and C. jejuni RM1221 ( $p=0.0097)$, separately (Figure 4).

The influence of $C$. jejuni 81116 on HT-29 cell viability was found to be insignificant ( $p>0.05)$ on both at 24 and 48 hours (Figure 4).

According to the 24 hour incubation results, we found that La, Lp and Lr CFSs statistically significantly decreased the viability of $C$. jejuni 81116 infected HT-29 cells ( $p=0.01$, $p=0.001$ and $p=0.0036$, respectively). According to the results of the 48 hour incubation, the viability of HT-29 cells infected with $C$. jejuni 81116 was found to be significantly decreased ( $p=0.008, p=0.001$, respectively) in the presence of La and Lf CFSs; however, Lr was found to significantly $(p<0.0001)$ increase the viability of infected HT-29 cells (Figure 5a).

According to the results of the 24 hour incubation, it was found that all CFSs statistically significantly $(p<0.0001)$ reduced the viability of $C$. jejuni RM1221 infected HT-29 cells. After 48 hours of incubation, we found that CFSs of La, Lf $(p<0.0001)$ and Lp decreased ( $p: 0.0004)$ the viability of C. jejuni RM1221 infected HT-29 cells (Figure 5b).

\section{DISCUSSION}

Our study showed inhibitory effects of CFSs, obtained from the Lactobacillus species on C. jejuni isolate in human adenocarcinoma (HT-29) cell culture, mimicking host conditions. Numerous studies have reported that $L$. acidophilus, L. gasseri, L. fermentum, L. johnsonii, L. reuteri, L. crispatus, L. paracasei, L. plantarum, and L.salivarius or their cell-free supernatants repress the growth of the Campylobacter species (15, 27-32). Consistent with previous results, our findings showed that at the first four hours of incubation, the growth of $C$. jejuni RM1221 was reduced by all lactobacilli CFSs, while C. jejuni 81116 was only significantly reduced by La and Lp CFSs in HT-29 cell cultures. After 24 hours, all CFSs reduced the growth of both C. jejuni RM1221 and 81116 strains, except CFSs of La, which did not alter the growth of $C$. jejuni 81116 .

It is well known that adhesion is one of the most important stage for the colonization of colon cells by microbes. Previous studies have found that $L$. acidophilus, L. casei, $L$. rhamnosus and $L$. plantarum decreased the adhesion of $C$. jejuni strains while $L$. rhamnosus and $L$. salivarius did not prevent the adhesion of $C$. jejuni $(15,29,33-36)$. In our study, we found that all CFSs decreased the adhesion of C. jejuni 81116 to HT-29 cells while the adhesion of $C$. jejuni RM1221 strain was found to be decreased in the presence of only CFSs of La and Lr. Although anti-adhesive properties of CFSs are shown to be strain-specific, we may conclude that lactobacillus strains have an inhibitory effect on the adhesion of $C$. jejuni strains in general.

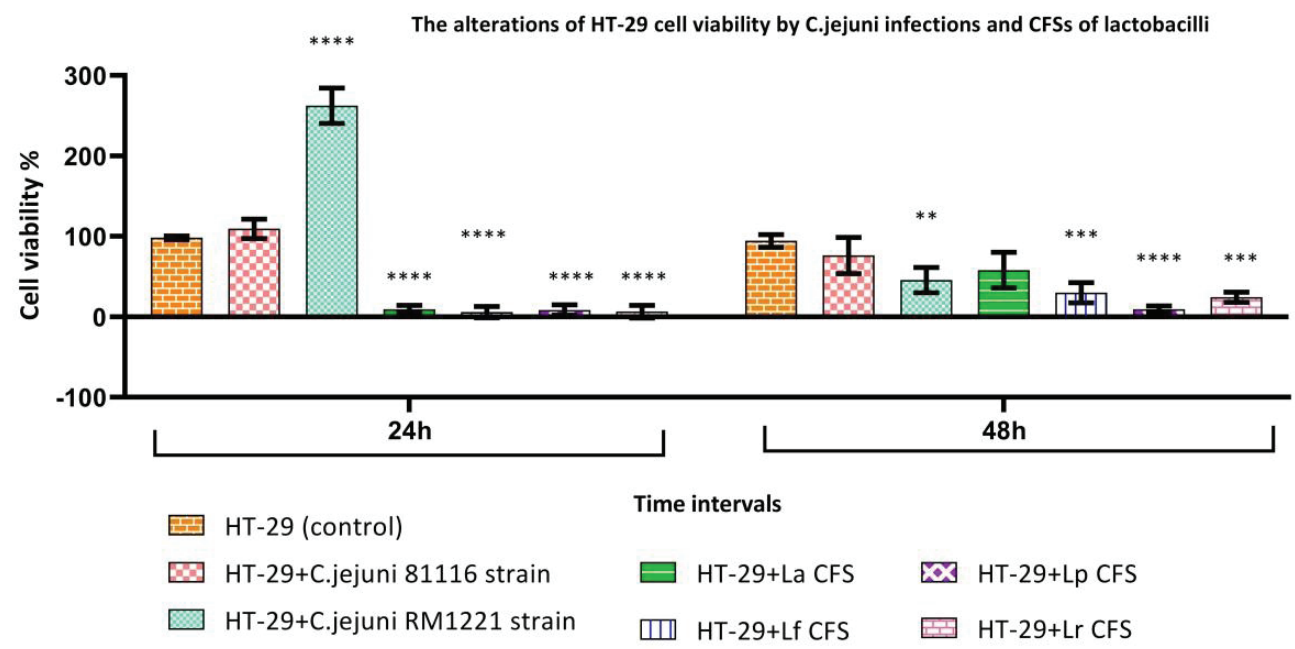

Figure 4: The influences of CFSs and C. jejuni infections, separately on HT-29 cell viabilities The cell viabilities with/without CFSs were analyzed using two-way ANOVA followed by Dunnett's multiple comparisons test $\star \star *, \star \star *, * \star \star \star *$ : Significant at $p=0.0097, p \leq 0.001$ and $p<0.0001$ levels, respectively. 
a The alterations of C.jejuni 81116 infected HT-29 cell viability with/without CFSs of lactobacilli

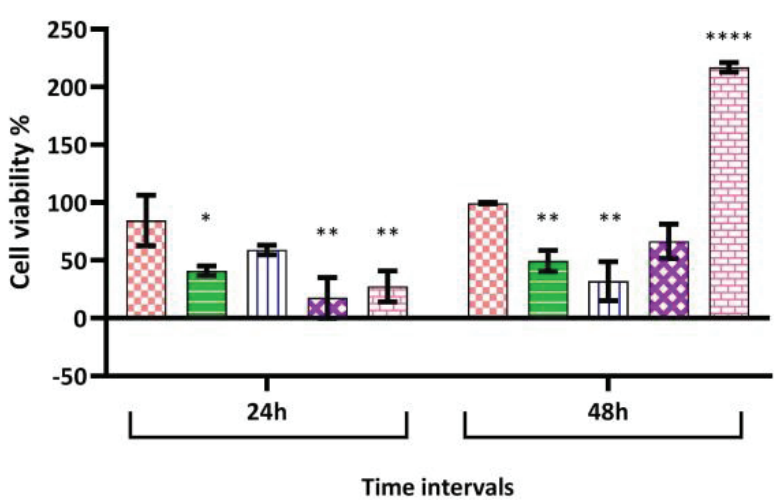
BT HT-29+C.jejuni 81116 strain
HT-29+C.jejuni 81116 strain+La CFS
HT-29+C.jejuni 81116 strain+Lp CFS
एा] HT-29+C.jejuni 81116 strain+Lf CFS
HT-29+C.jejuni 81116 strain+Lr CFS

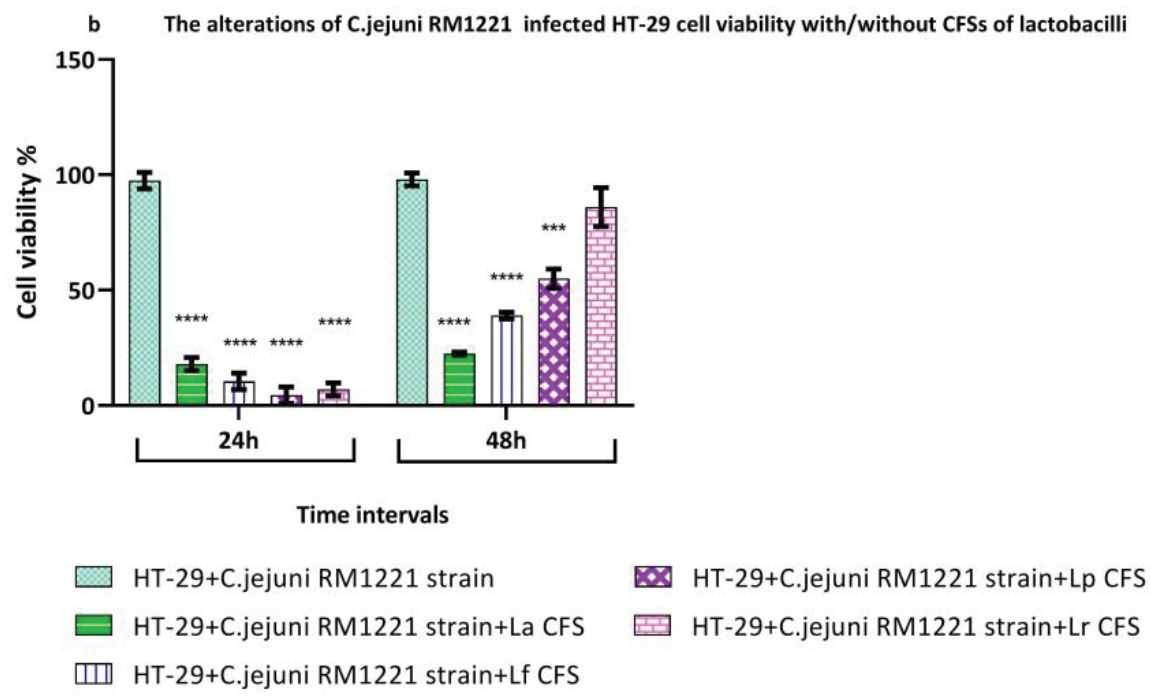

Figure 5: The influences of CFSs and C.jejuni infection co-presence on HT-29 cell viabilities

The cell viabilities with/without CFSs were analyzed using two-way ANOVA followed by Sidak's and Dunnett's multiple comparisons tests, respectively

$*, * *, * \star *, * \star \star *$ : Significant at $\mathrm{p}=0.01, \mathrm{p} \leq 0.008, \mathrm{p}<0.0005$ and $\mathrm{p}<0.0001$ levels, respectively.

Furthermore, invasion is another important stage during the infectious process. Although there are a limited number of studies investigating the effects of lactobacilli and their products on the invasion of $C$. jejuni, it appears that their effects are commonly defined as repressive. According to previous findings, L. helveticus, L. acidophilus, L. paracasei, L. rhamnosus, L. lactis, L. gasseri and L. salivarius, decrease the invasion of $C$. jejuni, but $L$. rhamnosus does not exhibit the same effect $(10,15,37)$. Consistent with Wine et al., we showed that CFSs did not alter the invasion of two $C$. jejuni strains tested.
In our study we did not analyze which mechanisms were responsible for the inhibition of adhesion and invasion processes. However, previous studies have proposed that probiotics could exclude and/or displace the pathogens in a competitive way $(15,37)$.

The influence of CFSs, C. jejuni and their combinations on HT-29 cell viability were also analyzed in our study. Many studies have reported that lactobacilli and their products affect the host cell viabilities (PSI cl.1, B1OXI, CLAB, Caco-2, HOB, HT-29, HeLa, AGS, MCF-7 and CF cell lines) $(13,34,39-41)$. While Pogačar et al. showed 
that L. plantarum and L. rhamnosus strains did not have any cytotoxic effects on pig and chicken epithelial cells at 24 hours of incubation, Kalaycı-Yüksek et al. reported that CFSs of La, Lf and Lp decreased the viability of HOB cells for three hours of incubation. Consistent with earlier research the viabilities of AGS, MCF-7, HT-29 and HeLa cells were found to be gradually reduced depending on incubation and concentration of L. acidophilus CFS (13, 41). We found in our study that all CFSs, except La, decreased the viability of HT-29 cells at both incubation periods. Presumably, the effects of lactobacilli and/or their products on cell viability may be related to their acidic $\mathrm{pH}$.

It has been shown that $C$. jejuni causes a cytotoxic effect on pig and chicken epithelial cells (34). However, Bouwman et al. have shown that different $C$. jejuni strains did not induce any cytotoxicity on macrophages. Interestingly, our results have shown that the effect of $C$. jejuni infection on the viability of HT-29 cells is strain-dependent. While C. jejuni 81116 did not affect the viability of HT-29 cells at both incubation periods, C. jejuni RM1221 increased at 24 hours. However, HT-29 cell viabilities were found to be decreased if the exposure was prolonged to 48 hours. We assume that cell viability is associated with exposure time, types of infected cell lines, and biological properties of $C$. jejuni strains tested.

Moreover, we investigated the effects of CFSs in combination with $C$. jejuni infection on host cell viability. L. plantarum and $L$. rhamnosus were shown to have protective effects on the viabilities of $C$. jejuni infected pig and chicken epithelial cells at 24 and 48 hours of incubation. It has also been shown that different lactobacilli combinations decreased the cell viabilities which were infected with $C$. jejuni at both 24 and 48 hours of incubation (34). Consistent with these findings, in our study, CFSs of La, Lp and Lr decreased the viability of HT-29 cells infected with C. jejuni 81116 at 24 hours of incubation. However, at 48 hours of incubation, the viability was increased in the presence of Lr CFSs. Furthermore, CFSs of Lf acted as a suppressive on the viability of $C$. jejuni 81116 infected-HT-29 cells. Similar results were observed on the HT-29 cell viabilities infected with C. jejuni RM1221 at 24 hours incubation. All CFSs decreased HT-29 cell viability, but suppressive effects of $L r$ disappeared when incubation was prolonged to 48 hours. It is clear that the influence of CFSs on the viability of infected HT-29 cells is strain-dependent.

In conclusion, the present study demonstrated that CFSs obtained from the Lactobacillus species showed inhibitory effects on $C$. jejuni growth and adhesive properties in cell culture. Furthermore, in this study, we found that CFSs have a suppressive effect on the viability of infected/non-infected HT-29 cells which may be related to the acidic properties of CFSs. Although our results showed that the inhibitory effects of CFSs vary depending on exposure time and strains, it is possible to suggest that their inhibitory effects on the biology of Campylobacter infections may be taken into consideration.

However there were some limitations in our study. Further clarity is needed as to which inhibitory products of lactobacilli have the most effective roles on pathogens. Also, molecular aspects could identify the mechanisms which are affected during these interactions. In this frame, our findings provide preliminary insights for in vivo future studies to focus on the identification of these inhibitory roles of lactobacilli.

Peer Review: Externally peer-reviewed.

Author Contributions: Conception/Design of Study- F.K.Y., D.G., M.A.K.; Data Acquisition- F.K.Y., D.G., M.A.K., A.U.Ö., V.G.; Drafting Manuscript- F.K.Y., D.G., A.U.Ö., V.G.; Critical Revision of Manuscript- F.K.Y., D.G., M.A.K.; Approval and AccountabilityF.K.Y., D.G., M.A.K., A.U.Ö., V.G.

Conflict of Interest: Authors declared no conflict of interest

Financial Disclosure: Authors declared no financial support.

\section{REFERENCES}

1. Sullivan $\AA$, Nord CE. Probiotics in human infections. J Antimicrob Chemother 2002;50(5):625-7. [CrossRef]

2. Oelschlaeger TA. Mechanisms of probiotic actions - A review. Int J Med Microbiol 2010;300(1):57-62. [CrossRef]

3. Bajaj BK, Claes IJJ, Lebeer S. Functional mechanisms of probiotics. J Microbiol Biotechnol Food Sci 2015;4(4):321-7. [CrossRef]

4. Food and Agriculture Organization of The United Nations, Food and Nutritions Paper, Probiotics in food health and nutritional properties and guidelines for evaluation. In: Joint FAO/WHO Expert Consultation on Evaluation of Health and Nutritional Properties of Probiotics in Food including Powder Milk with Live Lactic Acid Bacteria, 1-4 October 2001. p. 1-33. Available from: http://www.fao.org/3/a0512e/ a0512e.pdf

5. Morelli L, Zonenenschain D, Del Piano M, Cognein P. Utilization of the intestinal tract as a delivery system for urogenital probiotics. J Clin Gastroenterol 2004;38(Suppl 6):107-10. [CrossRef]

6. Meurman JH, Stamatova I. Probiotics: Contributions to oral health. Oral Dis 2007;13(5):443-51. [CrossRef]

7. Sullivan $\AA$, Nord CE. Probiotics and gastrointestinal diseases. J Infect Med 2005;257:78-92. [CrossRef]

8. Allos BM. Campylobacter jejuni infections: Update on emerging issues and trends. Clin Infect Dis 2001;32(8):12016. [CrossRef]

9. Kaakoush NO, Castaño-Rodríguez N, Mitchell HM, Man SM. Global epidemiology of campylobacter infection. Clin Microbiol Rev 2015;28(3):687-720. [CrossRef]

10. Nishiyama K, Seto Y, Yoshioka K, Kakuda T, Takai S, Yamamoto $Y$, et al. Lactobacillus gasseri sbt2055 reduces infection by and colonization of campylobacter jejuni. PLoS One 2014;9(9):1-9. [CrossRef] 
11. Mohan V. The role of probiotics in the inhibition of Campylobacter jejuni colonization and virulence attenuation. Eur J Clin Microbiol Infect Dis 2015;34(8):1503-13. [CrossRef]

12. Gümüş $D$, Yüksek FK, Bilgin $M$, Camadan FD, Küçüker $M A$. In Vitro Effects of Various Probiotic Products on Growth and Biofilm Formation of Clinical UPEC Strains. Acta Biol Marisiensis 2020;3(1):5-14. [CrossRef]

13. Kalaycı Yüksek F, Gümüş D, Gündoğan Gi, Anğ Küçüker M. Cell-Free Lactobacillus sp Supernatants Modulate Staphylococcus aureus Growth, Adhesion and Invasion to Human Osteoblast (HOB) Cells. Curr Microbiol 2021;78(1):125-32. [CrossRef]

14. Chen X, Liu XM, Tian F, Zhang Q, Zhang HP, Zhang H, et al. Antagonistic activities of Lactobacilli against Helicobacter pylori growth and infection in human gastric epithelial cells. J Food Sci 2012;77(1):9-14. [CrossRef]

15. Campana R, Federici S, Ciandrini E, Baffone W. Antagonistic activity of lactobacillus acidophilus ATCC 4356 on the growth and adhesion/invasion characteristics of Human Campylobacter jejuni. Curr Microbiol 2012;64(4):371-8. [CrossRef]

16. Parolin C, Marangoni A, Laghi L, Foschi C, Palomino RAÑ, Calonghi $N$, et al. Isolation of vaginal lactobacilli and characterization of anti-candida activity. PLoS One 2015;10(6):1-17. [CrossRef]

17. Forestier C, De Champs C, Vatoux C, Joly B. Probiotic activities of Lactobacillus casei rhamnosus: In vitro adherence to intestinal cells and antimicrobial properties. Res Microbiol 2001;152(2):167-73. [CrossRef]

18. Chen CC, Lai CC, Huang HL, Huang WY, Toh HS, Weng TC, et al. Antimicrobial activity of lactobacillus species against carbapenem-resistant enterobacteriaceae. Front Microbiol 2019;10:789. [CrossRef]

19. Wasfi R, Abd El-Rahman OA, Zafer MM, Ashour HM. Probiotic Lactobacillus sp. inhibit growth, biofilm formation and gene expression of caries-inducing Streptococcus mutans. J Cell Mol Med 2018;22(3):1972-83. [CrossRef]

20. Lua YA, Lin PP, Hsieh YM, Tsai CC. Lactic acid bacteria inhibit the growth of Vibrio parahaemolyticus and the invasion of Caco-2 cells. ScienceAsia 2019;45(6):562-71. [CrossRef]

21. Karska-Wysocki B, Bazo M, Smoragiewicz W. Antibacterial activity of Lactobacillus acidophilus and Lactobacillus casei against methicillin-resistant Staphylococcus aureus (MRSA). Microbiol Res 2010;165(8):674-86. [CrossRef]

22. Nigam A, Kumar A, Hv M, Bhola N. In-vitro Screening of antibacterial activity of lactic acid bacteria against common enteric pathogens. J Biomed Sci 2012;1(4):1-6.

23. Saha S, Tomaro-Duchesneau C, Rodes L, Malhotra M, Tabrizian M, Prakash S. Investigation of probiotic bacteria as dental caries and periodontal disease biotherapeutics. Benef Microbes 2014;5(4):447-60. [CrossRef]

24. Haddad N, Maillart G, Garénaux A, Jugiau F, Federighi M, Cappelier JM. Adhesion ability of Campylobacter jejuni to $\mathrm{Ht}-29$ cells increases with the augmentation of oxidant agent concentration. Curr Microbiol 2010;61(6):500-5. [CrossRef]

25. Xi D, Alter T, Einspanier R, Sharbati S, Gölz G. Campylobacter jejuni genes Cj1492c and Cj1507c are involved in host cell adhesion and invasion. Gut Pathog 2020;12(1):1-11. [CrossRef]

26. Mosmann T. Rapid Colorimetric Assay for Cellular Growth and Survival: Application to Proliferation and Cytotoxicity Assays. J immunological Methods 1983;65:55-63. [CrossRef]
27. Shahbazi Y, Mozaffarzogh M. Antimicrobial Effects of Lactobacillus acidophilus and Lactobacillus reuteri against Campylobacter jejuni in Fresh and Roasted Chicken Breast Fillets. J Human, Environ Heal Promot 2019;5(3):110-5. [CrossRef]

28. Bratz K, Gölz G, Janczyk P, Nöckler K, Alter T. Analysis of in vitro and in vivo effects of probiotics against Campylobacter spp. Berl Munch Tierarztl Wochenschr 2015;128(3-4):155-62.

29. Wang G, Zhao Y, Tian F, Jin X, Chen H, Liu X, et al. Screening of adhesive lactobacilli with antagonistic activity against Campylobacter jejuni. Food Control 2014;44:49-57. [CrossRef]

30. Santini C, Baffoni L, Gaggia F, Granata M, Gasbarri R, Di Gioia $D$, et al. Characterization of probiotic strains: An application as feed additives in poultry against Campylobacter jejuni. Int J Food Microbiol 2010;141(Suppl.):S98-108. [CrossRef]

31. Lehri B, Seddon AM, Karlyshev A V. Lactobacillus fermentum 3872 as a potential tool for combatting Campylobacter jejuni infections. Virulence 2017;8(8):1753-60. [CrossRef]

32. Taha-Abdelaziz K, Astill J, Kulkarni RR, Read LR, Najarian A, Farber JM, et al. In vitro assessment of immunomodulatory and anti-Campylobacter activities of probiotic lactobacilli. Sci Rep 2019;9(1):1-15. [CrossRef]

33. Salaheen S, White B, Bequette BJ, Biswas D. Peanut fractions boost the growth of Lactobacillus casei that alters the interactions between Campylobacter jejuni and host epithelial cells. Food Res Int 2014;62:1141-6. [CrossRef]

34. Šikić Pogačar M, Langerholc T, Mičetić-Turk D, Možina SS, Klančnik A. Effect of Lactobacillus spp. On adhesion, invasion, and translocation of Campylobacter jejuni in chicken and pig small-intestinal epithelial cell lines. BMC Vet Res 2020;16(1):1-14. [CrossRef]

35. Cresci GAM, Mayor PC, Thompson SA. Effect of butyrate and Lactobacillus GG on a butyrate receptor and transporter during Campylobacter jejuni exposure. FEMS Microbiol Lett 2017;364(6):3-8. [CrossRef]

36. Saint-Cyr MJ, Haddad N, Taminiau B, Poezevara T, Quesne $\mathrm{S}$, Amelot $\mathrm{M}$, et al. Use of the potential probiotic strain Lactobacillus salivarius SMXD51 to control Campylobacter jejuni in broilers. Int J Food Microbiol 2017;247:9-17. [CrossRef]

37. Wine E, Gareau MG, Johnson-Henry K, Sherman PM. Strain-specific probiotic (Lactobacillus helveticus) inhibition of Campylobacter jejuni invasion of human intestinal epithelial cells. FEMS Microbiol Lett 2009;300(1):146-52. [CrossRef]

38. Cean A, Stef L, Simiz E, Julean C, Dumitrescu G, Vasile $A$, et al. Effect of human isolated probiotic bacteria on preventing Campylobacter jejuni colonization of poultry. Foodborne Pathog Dis 2015;12(2):122-30. [CrossRef]

39. Chen ZY, Hsieh YM, Huang CC, Tsai CC. Inhibitory effects of probiotic Lactobacillus on the growth of human colonic carcinoma cell line HT-29. Molecules 2017;22(1):107. [CrossRef]

40. Sadeghi-Aliabadi H, Mohammadi F, Fazeli H, Mirlohi M. Effects of lactobacillus plantarum A7 with probiotic potential on colon cancer and normal cell proliferation in comparison with a commercial strain. Iran J Basic Med Sci 2014;17(10):815-9.

41. Nami $Y$, Abdullah N, Haghshenas B, Radiah D, Rosli R, Khosroushahi AY. Probiotic potential and biotherapeutic effects of newly isolated vaginal Lactobacillus acidophilus 36YL strain on cancer cells. Anaerobe 2014;28:29-36. [CrossRef] 